\title{
EKSPERIMENTASI MODEL PEMBELAJARAN \\ KOOPERATIF TIPE TEAMS GAMES TOURNAMENTS (TGT) YANG DIMODIFIKASI DENGAN ASSESSMENT FOR LEARNING (AFL) PADA PEMBELAJARAN MATEMATIKA DITINJAU DARI KREATIVITAS BELAJAR SISWA KELAS XI SMK TEKNIK DI KABUPATEN MADIUN TAHUN PELAJARAN 2015/2016
}

\author{
Suryanto $^{1}$, Budi Usodo ${ }^{2}$, dan Mardiyana ${ }^{3}$ \\ ${ }^{1,2,3}$ Prodi Magister Pendidikan Matematika, FKIP Universitas Sebelas Maret Surakarta
}

\begin{abstract}
The objective of this research was to investigate the effect of learning models on the learning achievement in Mathematics viewed from creativity of the student. The learning models compared were Teams Games Tournaments (TGT) The Modified By Assessment For Learning (AfL), Teams Games Tournaments (TGT) an direct model. This research is a quasi-experimental research with a $3 \times 3$ factorial design. The population of this research is all class $11^{\text {th }}$ student of Vocational High School in Madiun. Sampling was done by stratified cluster random sampling of the sample totaled 266 students, with details of 87 students in the experimental class of 90 students in two experimental classes and 89 students in the control class. The instruments used to collect data were mathematics achievement test and test creativity in learning. The technique of analyzing the data was two-ways ANOVA with unequal cells. The results of research showed that: (1) The model of cooperative learning TGT modified AfL provides mathematics learning achievement better than cooperative learning model TGT and direct learning. TGT cooperative learning model provides mathematics learning achievement as well as direct learning model; (2) Students who have a high learning creativity gives better mathematics learning achievement than students who have studied creativity medium and low. Students who have studied creativity is giving mathematics learning achievement as well as students with low learning creativity; (3) For each learning model show that, the prestige mathematics students with high creativity learning are better than the student who have medium or low, and students who have the creativity learning is giving better mathematics learning achievement than students with low learning creativity. (4) For each students' level of creativity show that, cooperative learning model TGT modified AfL provides mathematics learning achievement better than cooperative learning model TGT and direct learning. TGT cooperative learning model provides better mathematics learning achievement than direct learning model.
\end{abstract}

Keywords: cooperative learning, TGT modified AfL, TGT, creativity in learning, academic achievement.

\section{PENDAHULUAN}

Pendidikan merupakan bagian tak terpisahkan dari kehidupan manusia. Usaha pemerintah untuk meningkatkan mutu pendidikan nampak dari upaya pembaharuan serta penyempurnaan kurikulum yang telah dilaksanakan. Pada hakekatnya tujuan pembaharuan kurikulum tersebut adalah untuk menjawab masalah-masalah pendidikan yang timbul pada masa sekarang maupun masa yang akan datang.

Terkait dengan hal itu, pemerintah Indonesia bertanggung jawab mengembangkan sistem pengelolaan serta menggunakan kewenangannya menyiapkan 
SDM unggul lewat pembenahan sistem pendidikan nasional. Misalnya, menyelenggarakan program Afirmasi Pendidikan Tinggi (ADIK) dan Afirmasi Pendidikan Menengah (ADEM) untuk masyarakat Papua dan Papua Barat, mengadakan sertifikasi guru untuk meningkatkan profesionalisme dan dedikasi para guru, mengadakan pembenahan dan perubahan kurikulum pendidikan, meningkatkan sarana dan prasarana pendidikan dengan dana bantuan operasional sekolah (BOS) dan sebagainya. Pemerintah juga memperbaiki dan meningkatkan mutu pendidikan yang erat kaitannya dengan proses pembelajaran. Khususnya pendidikan matematika, upaya-upaya yang dilakukan pemerintah diantaranya mengadakan diklat, penataran, seminar, simposium, dan workshop untuk para guru matematika baik di tingkat nasional, provinsi, maupun kabupaten.

Berdasarkan data tentang Indeks Pembangunan Manusia (Human Development Index-HDI) pada tahun 2015 kualitas pendidikan Indonesia berada pada urutan 110 dari 188 negara di dunia. Peringkat Indonesia ini tergolong rendah, hanya dua tingkat di bawah negara Turki. Selain itu Indonesia berada pada posisi yang jauh bila dibandingkan negara ASEAN, seperti Thailand (93), Srilangka (73), Malaysia (62) apalagi dengan Singapura (11). (http://en.wikipedia.List_of_countries_by_HDI).

Pada tingkat provinsi Jawa Timur, hasil ujian nasional 2014/2015 berdasarkan data Dinas Pendidikan Jawa Timur disebutkan sebanyak 125.626 siswa peserta ujian nasional (UN) matematika SMK se-Jatim dinyatakan tidak lulus, mereka merupakan 64\% dari total peserta UN yang mencapai 195.363 siswa. Sedangkan hasil ujian nasional mata pelajaran matematika tingkat SMK di Kabupaten Madiun tahun pelajaran 2014/2015, yang tidak lulus sebanyak 2.196 siswa dari 3.849 siswa atau 57\%. Rata-rata nilai ujian nasional mata pelajaran matematika 52,46 dengan nilai tertinggi 100,0 dan nilai terendah 7,5. Berdasarkan hasil ujian nasional, prestasi belajar matematika belum sesuai harapan. Salah satu indikator kemampuan yang diujikan yang masih berada di bawah rata-rata nasional adalah kemampuan memecahkan masalah yang berkaitan dengan barisan dan deret. Persentase penguasaan materi memecahkan masalah yang berkaitan dengan barisan dan deret di tingkat kabupaten sebesar 29,74\% masih berada di bawah persentase di tingkat propinsi sebesar 33,65\% dan di bawah persentase tingkat nasional sebesar $38,47 \%$. Kemampuan yang diujikan pada ujian nasional materi barisan dan deret adalah menentukan rasio dari deret geometri tak hingga jika diketahui suku pertama dan jumlah deret tak hingganya. Berdasarkan wawancara dengan siswa, diperoleh bahwa siswa belum menguasai konsep barisan dan deret, sehingga dalam mengerjakan soal-soal yang berkaitan konsep barisan dan deret masih banyak yang mengalami kesulitan. 
Menurut penelitian Hasan Ismail (2014) menyatakan bahwa hambatan guru pada kegiatan pembelajaran adalah guru kurang disiplin waktu dalam melengkapi tugas administrasi, guru kesulitan mengelola proses pembelajaran, kurang kreatif dalam memilih model pembelajaran, guru belum begitu memahami pengembangan pembelajaran, dan guru kurang fokus terhadap materi yang diajarkan. Hal ini menyebabkan siswa merasa jenuh dan kurang termotivasi dalam belajar matematika.

Supaya pembelajaran matematika dapat menghasilkan prestasi belajar yang optimal, guru harus pandai memilih model pembelajaran yang mampu melibatkan siswa berperan aktif dalam proses pembelajaran. Bagaimanapun tepat dan baiknya bahan ajar matematika yang ditetapkan belum menjamin akan tercapainya tujuan pendidikan, dan salah satu faktor penting untuk mencapai tujuan tersebut adalah proses pembelajaran yang lebih menekankan pada keterlibatan siswa secara optimal. Semua model pembelajaran kooperatif menyumbangkan ide bahwa siswa yang bekerja sama dalam belajar dan bertanggung jawab terhadap teman satu timnya dan membuat diri mereka belajar sama baiknya. Oleh karena itu tugas-tugas yang diberikan kepada siswa bukan melakukan sesuatu sebagai sebuah tim tetapi belajar sesuatu sebagai tim (Slavin, 2005)

Pembelajaran kooperatif merupakan sebuah model pembelajaran yang melibatkan siswa bekerja secara kolaborasi untuk mencapai tujuan bersama (Eggen and Kauchak dalam Trianto, 2009). Menurut Wina Sanjaya (2006:242) bahwa pembelajaran kooperatif merupakan model pembelajaran dengan menggunakan sistem pengelompokan/tim kecil antara empat sampai enam orang yang mempunyai latar belakang kemampuan akademik, jenis kelamin, ras, atau suku yang berbeda (heterogen). Sistem penilaian dilakukan secara kelompok. Setiap kelompok akan memperoleh penghargaan (reward), jika kelompok mampu menunjukkan prestasi yang dipersyaratkan. Dengan demikian, setiap anggota kelompok mempunyai ketergantungan positif. Ketergantungan inilah yang selanjutnya memunculkan tanggung jawab individu terhadap kelompok dan keterampilan interpersonal dari setiap anggota kelompok. Setiap individu akan saling membantu, mereka mempunyai motivasi untuk keberhasilan kelompok, sehingga setiap individu memiliki kesempatan yang sama untuk memberikan kontribusi demi keberhasilan kelompok.

Teams Games Tournaments (TGT) pada mulanya dikembangkan oleh David dan Keath TGT adalah salah satu model pembelajaran kooperatif yang menempatkan siswa dalam kelompok-kelompok belajar yang beranggotakan 5 sampai dengan 6 siswa yang memiliki kemapuan, jenis kelamin, dan suku atau ras yang berbeda (Slavin, 2005). Pembelajaran kooperatif tipe TGT terdiri dari 5 tahap yaitu : penyajian kelas (class 
presentation), belajar dalam kelompok (teams study), permainan (games), pertandingan (tournament), dan perhargaan kelompok (team recognition). Menurut Grabowski dan Ke (2007:256) Teknik kooperatif TGT lebif efektif dibandingkan persaingan antar individu dalam menfasilitasi sikap positif dalam matematika.

Setelah teams study pada pembelajaran model TGT selesai, dilanjutkan games tournament tanpa adanya kesiapan setiap siswa dalam kelompok, apakah setiap siswa benar-benar sudah siap maju ke turnamen? Oleh karena itu, dalam penelitian ini model pembelajaran TGT perlu dimodifikasi dengan menambahkan suatu langkah pembelajaran setelah kegiatan kelompok yaitu Assessment for Learning (AfL) dengan pemberian kuis secara individual yang hasilnya dibahas di dalam kelompok belajar, untuk memastikan bahwa setiap siswa telah menguasai materi pelajaran dan mengukur kesiapan setiap siswa maju ke meja turnamen. Noonan dan Duncan (2005), Onuka (2007), Thomas, et. al. (2011) menyatakan penilaian teman dalam kelompok dapat meningkatkan prestasi siswa serta mampu membina karakter siswa, misalnya tanggung jawab, kejujuran dan penilaian diri. Penilaian untuk belajar (Assessment for Learning -AfL) bukanlah hal baru dalam penilaian guru. Penilaian untuk belajar dikembangkan melalui perpaduan antara hasil penelitian dan praktik penilaian dalam kelas. Prinsip-prinsip yang mendasari lahirnya penilaian disusun dari kesimpulan hasil reviu penilaian formatif yang dilakukan oleh Black dan William dalam Harun Rasyid dan Mansur (2009), yaitu: (1) Keterlibatan aktif dari siswa dalam kegiatan belajarnya, (2) Provisi umpan balik yang efektif untuk siswa, (3) Pengaruh dari penilaian dalam memotivasi rasa percaya diri siswa, yang juga memberikan pengaruh penting dalam pembelajaran, (4) Keterbatasan dari siswa untuk mengakses dirinya sendiri dan mengerti bagaimana untuk meningkatkanya, (5) Penambahan jam mengajar untuk memperhitungkan hasil penilaian.

Langkah-langkah model pembelajaran kooperatif tipe TGT yang dimodifikasi AfL: (1) Tahap Penyajian Kelas (Class Presentation), (2) Belajar Kelompok (Teams Study), (3) Penilaian untuk Belajar (Assessment for Learning), (4) Belajar Kelompok (Teams Study), (5) Permainan (Games Tournament), (6) Penghargaan Kelompok (Teams Recognition)

Selain model pembelajaran ada faktor lain yang mempengaruhi prestasi belajar salah satunya adalah kreativitas belajar siswa. Galligan (2006: 20-21) menyatakan bahwa kreativitas itu penting dalam semua aspek pembaharuan dan kemajuan budaya, memerlukan imajinasi, disiplin, dan dukungan. Haefele dalam Utami Munandar (2004: 21) menyatakan bahwa "kreativitas adalah kemampuan untuk membuat kombinasikombinasi baru yang mempunyai makna sosial”. Tingkat kreativitas belajar siswa dapat 
dikategorikan ke dalam tingkat kreativitas belajar tinggi, sedang, atau rendah. Kreativitas merupakan kemampuan berpikir untuk membuat kombinasi baru dalam menghasilkan gagasan, jawaban, atau pertanyaan berdasarkan data, informasi, atau unsur-unsur yang ada dalam menyelesaikan masalah. Perbedaan kreativitas belajar setiap siswa ini juga dapat menjadi bahan pertimbangan bagi guru dalam memilih suatu model pembelajaran yang tepat untuk diterapkan dalam kegiatan pembelajaran dan efektif dalam meningkatkan prestasi belajar matematika siswa.

Penelitian ini bertujuan untuk mengetahui: (1) Manakah yang menghasilkan prestasi belajar matematika lebih baik model pembelajaran kooperatif tipe TGT yang dimodifikasi AfL, TGT atau model pembelajaran langsung. (2) Manakah yang mempunyai prestasi belajar matematika lebih baik, siswa yang memiliki kreativitas belajar tinggi, sedang, atau rendah. (3) Pada masing-masing model pembelajaran, manakah yang mempunyai prestasi belajar matematika lebih baik, siswa dengan kreativitas belajar tinggi, sedang, atau rendah. (4) Pada masing-masing tingkatan kreativitas belajar siswa, manakah yang memberikan prestasi belajar matematika yang lebih baik, model pembelajaran kooperatif TGT yang dimodifikasi AfL, TGT atau pembelajaran langsung.

\section{METODE PENELITIAN}

Penelitian ini merupakan penelitian eksperimental semu dengan rancangan penelitian yang digunakan adalah rancangan faktorial $3 \times 3$. Populasi dalam penelitian ini adalah seluruh siswa kelas XI SMK Kelompok Teknik di Kabupaten Madiun tahun pelajaran 2015/2016. Teknik pengambilan sampel menggunakan teknik stratified cluster random sampling. Berdasarkan teknik sampling yang digunakan diperoleh bahwa sampel-sampel yang digunakan SMKN 1 Geger mewakili sekolah kategori tinggi, SMKN 1 Kebonsari mewakili sekolah kategori sedang, dan SMK Muhamdiyah 3 Dolopo mewakili sekolah kategori rendah.

Variabel bebas dalam penelitian ini adalah model pembelajaran dan kreativitas belajar siswa, sedangkan variabel terikatnya adalah prestasi belajar matematika. Metode pengumpulan data yang digunakan adalah metode angket, metode tes, dan metode dokumentasi. Metode angket dilakukan untuk memperoleh data kreativitas belajar siswa dan metode tes digunakan untuk memperoleh data prestasi belajar matematika, sedangkan metode dokumentasi digunakan untuk memperoleh data sampel penelitian dan data kemampuan awal siswa. Data kemampuan awal diambil dari nilai Ulangan Akhir Semester Gasal tahun pelajaran 2015/2016 siswa. Data tersebut digunakan untuk uji 
prasyarat dilakukannya penelitian. Instrumen yang digunakan dalam penelitian ini berupa angket kreativitas belajar dan tes prestasi belajar matematika pada materi barisan dan deret yang sebelumnya telah diuji validitas dan reliabilitas instrumennya. Sebelum penelitian dilakukan, peneliti terlebih dahulu melakukan uji keseimbangan antara tiga kelompok populasi dengan uji anava satu jalan sel tak sama. Selanjutnya dilakukan pengujian hipotesis dengan menggunakan uji analisis variansi dua jalan sel tak sama. Pengujian berikutnya adalah uji lanjut pasca anava dengan menggunakan metode Scheffe' yang meliputi uji komparasi ganda antar baris, uji komparasi ganda antar kolom dan uji komparasi ganda antar sel.

\section{HASIL PENELITIAN DAN PEMBAHASAN}

Hasil uji keseimbangan pada penelitian menggunakan uji analisis variansi satu jalan sel tak sama. Hasil uji keseimbangan tersebut terangkum dalam Tabel 1.

Tabel 1. Rangkuman Analisis Variansi Satu Jalan Sel Tak Sama

\begin{tabular}{lrrrcrl}
\hline \multicolumn{1}{c}{ Sumber } & \multicolumn{1}{c}{ JK } & \multicolumn{1}{c}{$\mathrm{dk}$} & \multicolumn{1}{c}{$\mathrm{RK}$} & \multicolumn{1}{c}{$\mathrm{F}_{\mathrm{obs}}$} & \multicolumn{1}{c}{$\mathrm{F}_{\alpha}$} & Keputusan \\
\hline Model & 705,1601 & 2 & 325,5580 & 2,2497 & 3,000 & $H_{0}$ diterima \\
Pembelajaran & & & & & \\
Galat & 41215,0644 & 263 & 156,7113 & & & \\
Total & 41920,1805 & 265 & & & & \\
\hline
\end{tabular}

Berdasarkan Tabel 1 dapat dilihat $F_{o b s}$ sebesar 2,2479 dan $F_{\alpha}$ sebesar 3,000. Karena $F_{o b s}<F_{\alpha}$ maka $H_{0}$ diterima sehingga disimpulkan bahwa populasi mempunyai kemampuan awal yang sama (seimbang).

Selanjutnya dilakukan uji hipotesis menggunakan anava dua jalan dengan sel tak sama. Hasil uji anava dua jalan sel tak sama ini terangkum dalam Tabel 2.

Tabel 2. Rangkuman Analisis Variansi Dua Jalan Sel Tak Sama

\begin{tabular}{|c|c|c|c|c|c|c|}
\hline Sumber Data & $\mathrm{JK}$ & $\mathrm{dk}$ & RK & $\mathrm{F}_{\mathrm{obs}}$ & $\mathrm{F}_{\alpha}$ & Keputusan \\
\hline $\begin{array}{l}\text { Model Pemb. } \\
\text { (A) }\end{array}$ & 4410,0921 & 2 & 2205,0460 & 12,5460 & 3,000 & Ho ditolak \\
\hline Kreativitas (B) & 3634,1366 & 2 & 1817,0683 & 10,3385 & 3,000 & Ho ditolak \\
\hline Interaksi (AB) & 193,4730 & 4 & 48,3682 & 0,2752 & 2,407 & Ho diterima \\
\hline Galat (G) & 45169,6968 & 257 & 175,7576 & - & - & - \\
\hline Total (T) & 53407,3985 & 265 & & & & \\
\hline
\end{tabular}

Dari hasil perhitungan $F_{o b s}>F_{\alpha}$ untuk $H_{0 \mathrm{~A}}, F_{o b s}>F_{\alpha}$ untuk $H_{0 \mathrm{~B}}$ dan $F_{o b s}<F_{\alpha}$ untuk $H_{0 \mathrm{AB}}$, sehingga diperoleh kesimpulan sebagai berikut: 1) terdapat perbedaan efek pada model pembelajaran terhadap prestasi belajar matematika siswa, 2) terdapat perbedaan efek pada kreativitas belajar siswa terhadap prestasi belajar matematika siswa, 
dan 3) tidak terdapat interaksi antara model pembelajaran dan kreativitas belajar siswa terhadap prestasi belajar matematika siswa.

Karena kedua hipotesis ditolak, serta satu hipotesis diterima maka diperlukan uji lanjut pasca anava yakni uji komparasi ganda antar baris dan antar kolom dengan metode Scheffe'. Sebelum dilakukan uji komparasi ganda antar baris, terlebih dahulu dihitung rerata marginalnya. Hasil perhitungan rerata tersebut disajikan dalam Tabel 3.

Tabel 3. Rerata Marginal Prestasi Belajar Matematika

\begin{tabular}{lcccc}
\hline \multirow{2}{*}{ Model Pembelajaran } & \multicolumn{2}{c}{ Kategori Kreativitas Belajar } & \multirow{2}{*}{ Rerata } \\
\cline { 2 - 4 } & Tinggi & Sedang & Rendah & Marginal \\
\hline TGT modif AfL & 81,9259 & 78,0952 & 70,8889 & 77,7931 \\
TGT & 77,0769 & 70,5306 & 65,8667 & 71,6444 \\
Langsung & 68,9091 & 67,5472 & 61,1429 & 66,8704 \\
Rerata Marginal & 76,4267 & 71,6389 & 66,3830 & \\
\hline
\end{tabular}

Tabel 3 digunakan untuk melihat rerata marginal dari masing-masing model pembelajaran dan kategori kreativitas belajar siswa apabila dari perhitungan uji komparasi ganda berikut dinyatakan terdapat perbedaan yang signifikan.

Hasil uji ANAVA dua jalan sel tak sama menunjukkan $H_{0 A}$ ditolak, sehingga perlu dilakukan uji komparasi ganda antar baris. Rangkuman hasil uji rerata antar baris disajikan pada Tabel 4.

Tabel 4. Rangkuman Komparasi Ganda Antar Baris

\begin{tabular}{cccc}
\hline$H_{0}$ & $F_{o b s}$ & $F_{\alpha}$ & Keputusan Uji \\
\hline$\mu_{1}=\mu_{2}$. & 9,5156 & 6,000 & Ditolak \\
$\mu_{1}=\mu_{3}$. & 29,8308 & 6,000 & Ditolak \\
$\mu_{2}=\mu_{3}$. & 5,7882 & 6,000 & Diterima \\
\hline
\end{tabular}

Berdasarkan Tabel 4 diketahui terdapat perbedaan prestasi belajar matematika antara siswa yang diberi model pembelajaran TGT yang dimodifikasi AfL dengan model pembelajaran TGT maupun model pembelajaran langsung. Dengan memperhatikan rerata marginal pada Tabel 3, dapat disimpulkan bahwa prestasi belajar matematika siswa yang diberi model pembelajaran TGT yang dimodifikasi AfL lebih baik daripada siswa yang diberi pembelajaran TGT maupun pembelajaran langsung. Ini sesuai dengan hipotesis yang menyatakan bahwa model pembelajaran TGT yang dimodifikasi AfL menghasilkan prestasi belajar yang lebih baik daripada pembelajaran TGT maupun pembelajaran langsung. Hal ini disebabkan karena dalam model pembelajaran TGT yang dimodifikasi AfL, guru lebih banyak memfasilitasi, merancang skenario masalah, memberikan clueindikasi-indikasi tentang bacaan tambahan, arahan dan saran yang diperlukan saat siswa menjalankan proses. Dengan adanya AfL sebagai kontrol untuk menyiapkan siswa maju 
ke turnamen, menyebabkan siswa lebih aktif dalam proses pembelajaran. Pembelajaran langsung membuat siswa cenderung pasif, tidak bertanya kepada teman atau guru jika terdapat kendala dalam memahami materi sehingga anak kurang mengerti materi yang disampaikan. Hasil tersebut sesuai dengan penelitian dari Suwartarathip dan Wichadee (2010) yang menyimpulkan bahwa pembelajaran kooperatif dapat meningkatkan prestasi belajar siswa dan penelitian Dismas Suparmo (2013) menyimpulkan bahwa siswa yang dikenai pembelajaran yang menerapkan AfL melalui penilaian teman sejawat mempunyai prestasi belajar matematika lebih baik daripada siswa yang dikenai pembelajaran langsung.

Berdasarkan Tabel 4 diketahui tidak terdapat perbedaan yang signifikan prestasi belajar matematika antara siswa yang diberi model pembelajaran TGT dan model pembelajaran langsung, sehingga dapat disimpulkan bahwa prestasi belajar matematika siswa yang diberi model pembelajaran TGT sama baiknya dengan siswa yang diberi model pembelajaran langsung. Ini berbeda dengan hipotesis yang menyatakan bahwa model pembelajaran TGT menghasilkan prestasi belajar yang lebih baik daripada pembelajaran langsung. Hal ini disebabkan pembelajaran TGT siswa masih bingung tentang apa yang dilakukan dalam kelompok, bagaimana menyelesaikan permasalahan dalam kelompok serta masih canggung dalam menyampaikan idea atau gagasan dalam kelompok. Begitu pula saat turnamen siswa masih malu-malu dan belum mempunyai kepercayaan diri yang tinggi.

Hasil uji ANAVA dua jalan sel tak sama menunjukkan $H_{0 B}$ ditolak, sehingga perlu dilakukan uji komparasi ganda antar kolom. Rangkuman hasil uji rerata antar kolom disajikan pada Tabel 5.

Tabel 5. Rangkuman Komparasi Ganda Antar Kolom

\begin{tabular}{cccc}
\hline$H_{0}$ & $F_{o b s}$ & $F_{\alpha}$ & Keputusan Uji \\
\hline$\mu_{\cdot 1}=\mu_{\cdot 2}$ & 6,4318 & 6,000 & Ditolak \\
$\mu_{\cdot 1}=\mu_{\cdot 3}$ & 16,5833 & 6,000 & Ditolak \\
$\mu_{\cdot 2}=\mu_{\cdot 3}$ & 5,5694 & 6,000 & Diterima \\
\hline
\end{tabular}

Berdasarkan Tabel 5 diketahui terdapat perbedaan prestasi belajar matematika siswa dengan kreativitas tinggi, sedang dan rendah. Dengan memperhatikan rerata marginal pada Tabel 3, dapat disimpulkan bahwa prestasi belajar matematika siswa dengan kreativitas tinggi lebih baik daripada siswa dengan kreativitas sedang maupun rendah. Hal ini dikarenakan siswa dengan tingkat kreativitas tinggi mampu mengatasi permasalahan pembelajaran dengan mendiskusikan/ menanyakan masalah tersebut kepada guru maupun siswa lain sehingga diperoleh solusinya dan memperoleh lebih 
banyak ide, gagasan dan informasi baik dari guru maupun teman sebayanya. Hasil tersebut sesuai dengan penelitian yang dilakukan Puji Ayuni (2014) yang menyimpulkan bahwa terdapat perbedaan pengaruh kreativitas belajar terhadap prestasi belajar matematika pada materi program linier. Prestasi belajar siswa yang mempunyai kreativitas belajar tinggi lebih baik daripada kreativitas belajar sedang dan rendah

Berdasarkan Tabel 5 diketahui tidak terdapat perbedaan yang signifikan prestasi belajar matematika siswa yang mempunyai kreativitas belajar sedang dan rendah. Hal ini berbeda dengan hipotesis yang menyatakan bahwa prestasi belajar matematika siswa yang mempunyai kreativitas belajar sedang lebih baik daripada siswa yang mempunyai kreativitas belajar rendah. Faktor-faktor yang menyebabkan siswa memiliki prestasi belajar yang sama pada kreativitas belajar sedang dan rendah yaitu dalam pengisian angket siswa cenderung asal-asalan karena angket tersebut tidak dinilai dan masuk dalam nilai rapot. Alasan lain adalah siswa cenderung memilih pilihan yang baik-baik saja. Beberapa faktor tersebut menyebabkan hipotesis penelitian tidak sesuai harapan.

Berdasarkan hasil analisis variansi pada Tabel 2 diperoleh kesimpulan bahwa tidak terdapat interaksi antara model pembelajaran dan tingkat kreativitas belajar siswa terhadap prestasi belajar matematika siswa pada materi barisan dan deret. Oleh karena itu untuk mengetahui keefektifan kreativitas belajar siswa pada masing-masing model pembelajaran mengacu pada kesimpulan perbandingan rerata marginalnya.Setelah memperhatikan rerata marginal pada Tabel 3, dapat disimpulkan bahwa pada masingmasing model pembelajaran, prestasi belajar siswa yang memiliki kreativitas belajar tinggi lebih baik daripada sedang maupun rendah dan kreativitas belajar sedang lebih baik daripada rendah.

Hasil ini sejalan dengan penelitian Puji Ayuni (2014) yang menyimpulkan bahwa pada masing-masing model pembelajaran, prestasi belajar siswa yang memiliki kreativitas belajar tinggi lebih baik daripada sedang maupun rendah dan kreativitas belajar sedang lebih baik daripada rendah. Hal senada diungkapkan Yoppy Wahyu Purnomo (2011) bahwa kreativitas yang lebih tinggi memberikan hasil belajar lebih baik daripada kreativitas yang lebih rendah. Hal ini dikarenakan siswa dituntut memikirkan dan bertindak dengan berbagai cara untuk dapat menggunakan kompleksitas tantangan dan memikirkan berbagai alternatif tindakan yang dapat dilakukan untuk menghadapi tantangan, untuk itulah seseorang membutuhkan kreativitas (Depdiknas, 2008:7). Semakin tinggi tingkat kreatvitas semakin tinggi pula hasil belajarnya.

Berdasarkan hasil analisis variansi pada Tabel. 2 diperoleh kesimpulan bahwa tidak terdapat interaksi antara model pembelajaran dan tingkat kreativitas belajar siswa 
terhadap prestasi belajar matematika pada materi barisan dan deret. Oleh karena itu untuk mengetahui keefektifan model pembelajaran pada masing-masing tingkatan kreativitas belajar siswa mengacu pada kesimpulan perbandingan rerata marginalnya. Bisa disimpulkan bahwa pada masing-masing tingkat kreativitas belajar siswa, prestasi belajar siswa yang diberi model pembelajaran TGT yang dimodifikasi AfL lebih baik daripada model pembelajaran TGT maupun langsung dan prestasi belajar siswa yang diberi model pembelajaran TGT lebih baik daripada model pembelajaran langsung.

Hal ini sejalan dengan penelitian Noonan dan Duncan (2005), Onuka (2007), Thomas, et al. (2011) menyatakan penilaian teman dalam kelompok dapat meningkatkan prestasi siswa serta mampu membina karakter siswa, Stiggins dan Chappuis (2006) bahwa AfL dapat meningkatkan kesuksesan siswa, dan Dewi Susilowati (2004), yang menyimpulkan bahwa terdapat perbedaan prestasi belajar matematika yang signifikan yaitu bagi siswa yang mengikuti pembelajaran matematika dengan menggunakan model pembelajaran kooperatif tipe TGT lebih baik dibandingkan dengan siswa yang mengikuti pembelajaran secara langsung.

\section{SIMPULAN DAN SARAN}

Berdasarkan hasil analisis dan pembahasan yang telah diuraikan sebelumnya, dapat disimpulkan sebagai berikut. (1) Model pembelajaran kooperatif tipe TGT yang dimodifikasi AfL memberikan prestasi belajar matematika lebih baik daripada model pembelajaran kooperatif tipe TGT maupun pembelajaran langsung. Model pembelajaran kooperatif TGT memberikan prestasi belajar matematika sama baiknya dengan model pembelajaran langsung; (2) Siswa yang mempunyai kreativitas belajar tinggi memberikan prestasi belajar matematika lebih baik daripada siswa yang mempunyai kreativitas belajar sedang maupun rendah. Siswa yang mempunyai kreativitas belajar sedang memberikan prestasi belajar matematika sama baiknya dengan siswa yang mempunyai kreativitas belajar rendah; (3) Pada masing-masing model pembelajaran menunjukkan bahwa prestasi belajar matematika siswa dengan kreativitas belajar tinggi lebih baik daripada siswa dengan kreativitas belajar sedang maupun rendah, dan prestasi belajar matematika siswa dengan kreativitas belajar sedang lebih baik daripada siswa yang mempunyai kreativitas belajar rendah; (4) Pada masing-masing tingkat kreativitas belajar menunjukkan bahwa prestasi belajar matematika siswa dengan model pembelajaran kooperatif tipe TGT yang dimodifikasi AfL lebih baik daripada model pembelajaran kooperatif tipe TGT maupun pembelajaran langsung, dan prestasi belajar matematika 
siswa dengan model pembelajaran kooperatif tipe TGT lebih baik daripada model pembelajaran langsung.

Saran terkait hasil penelitian tersebut adalah guru memperluas wawasannya mengenai model pembelajaran, seperti model pembelajaran TGT yang dimodifikasi AfL dan TGT untuk diterapkan dalam penerapan proses pembelajaran. Guru sebaiknya juga memperhatikan tingkat kreativitas belajar yang dimiliki siswa agar proses pembelajaran dapat berlangsung dengan baik dan menghasilkan prestasi belajar yang maksimal. Bagi peneliti lain, diharapkan dapat meneruskan atau mengembangkan penelitian ini dengan variabel/ model lain yang lebih inovatif, sehingga dapat meningkatkan kualitas pembelajaran khususnya dan pendidikan pada umumnya.

\section{DAFTAR PUSTAKA}

Budiyono. 2003. Metodologi Penelitian Pendidikan. Edisi ke-1. Surakarta: UNS Press.

Budiyono. 2009. Statistika untuk Penelitian. Edisi ke-2. Surakarta: UNS Press.

Dewi Susilowati. 2004. Pengaruh Metode Pembelajaran Kooperatif Tipe Teams Games Tournaments (TGT) terhadap Prestasi Belajar Matematika Ditinjau dari Motivasi Belajar Siswa SLTP Negeri se-Kecamatan Sukoharjo. Surakarta: UNS Surakarta.

Depdiknas. 2008. Kreativitas. Jakarta: Ditjend PMPTK Depdiknas.

Dismas Suparmo, 2013. Pengembangan Model Assessment for Learning (AfL) Melalui Penilaian Teman Sejawad pada Pembelajaran Matematika pada Pokok Bahasan Trigonometri Ditinjau dari Gaya Belajar Siswa SMA Negeri Karangpandan Tahun Pelajaran 2012/2013. Tesis. Surakarta: UNS Surakarta.

Gallian, Ann. 2006. Art, Culture and the National Agenda. The Journal of Creativity, Culture, Educational, and The Workforce, (28:6) 20-21. Washington, D.C.

Grabowski, B dan Ke, F. 2007. Gameplaying for maths learning: cooperative or not? British Journal of Educational and Technology. Vol. 38. No. 2. Hal. 249-259

Harun Rasyid dan Mansur. 2009. Penilaian Hasil Belajar. Bandung: Wacana Prima.

Hasan Ismail. 2014. Identifikasi Hambatan Guru pada Pelaksanaan Pembelajaran Tematik di SDN Wonosari IV Gunung Kidul. Skripsi. Yogyakarta: UNY

Human Development Reports. 2015. The Human Development Index-Going Beyind Income. Washington, DC. Diakses pada 2 April 2016 dari (http://en.wikipedia.List_of_countries_by_HDI)

Noonan, B. dan Duncan, C.R. 2005. Peer and self-assessment in high schools. Pratical Assessment, Research, \& Evaluation. 10(17). 1 - 8. Diakses dari https://pareonline.net/getvn.asp?v=10\&n=17 pada 3 Maret 2016 
Onuka, A. O. U. 2007. Teacher-initiated student-peer assessment: A means of improving learning-assessment in large classes. International Journal of African \& African American Studies. 6(1). 18-24. Diakses dari http://ojcs.siue.edu/ojs/index.php/ijaaas/article/view/86/146 pada 3 Maret 2016.

Puji Ayuni, 2014. Eksperimentasi Model Pembelajaran Kooperatif Tipe Teams Games Tournament dan Student Teams Achievement Division Berbantuan Media Geogebra pada Materi Program Linear Ditinjau dari Kreativitas Belajar Siswa Kelas XII IPA SMA Negeri Se-Kabupaten Kudus Tahun Pelajaran 2013/2014. Tesis. Surakarta: UNS Surakarta

Slavin, R. E. 2005. Cooperative Learning: theory, research, and practice: Allyn and Bacon.

Stiggins, R. and Chappuis, J. 2006. What a different a word makes: Assessment FOR learning rather than assessment OF learning help student succeed. Diakses dari http://www.nsdc.org/library/publication/jsd. pada 24 Maret 2016

Suwantarathip, O. dan Wichadee, S. 2010. The Impact of Cooperative Learning on Anxiety and Proficiency in an EFL Class. Journal of College Teaching and Learning. Littleton: Vol. 7, Iss. 11;pg. 51-57

Thomas, G., Martin, D. and Pleasants, K. 2011. Using self-and peer-assessment to enhance students' future in higher education. Journal of University Teaching \& Learning Practice. 8(1). Diakses dari http://ro.uow.edu.au/jutlp/vol8/iss1/5. Pada 2 Juni 2016

Tim Penyususun Kamus Pusat Pembinaan dan Pengembangan Bahasa. 2001. Kamus Besar Bahasa Indonesia. Jakarta: Balai Pustaka.

Trianto. 2009. Mendesain Model Pembelajaran Inovatif-Progresif. Jakarta: Kencana Prenada Media Group.

Undang-Undang. 2003. Undang-Undang, Nomor 20, Tahun 2003, tentang Sistem Pendidikan Nasional.

Utami Munandar. 2004. Memupuk Bakat dan Kreativitas Siswa Sekolah Menengah. Jakarta: Gramedia Widiasarana.

Utami Munandar. 2009. Pengembangan Kreativitas Anak Berbakat. Jakarta: Rineka Cipta

Wina Sanjaya. 2006. Strategi Pembelajaran. Jakarta: Kencana Prenada Media Group.

Yoppy Wahyu Purnomo. 2011. Efektivitas Model Penemuan Terbimbing dan Cooperative Learninf Ditinjau dari Kreativitas Siswa pada Pembelajaran Matematika di Kelas IX SMP se-sub Rayon 04 Kabupaten Wonogiri Tahun Pelajaran 2010/2011. Tesis. Surakarta: UNS Surakarta. 